$U D C 78.072 .2$

DOI $10.33287 / 222006$

Furduy Yulia,

PhD in Arts, the docent

of the ,History and Theory of Music” chair, Dnipropetrovsk Music Academy after Mikhail Glinka tel. (067) 810 - 46 - 99 e-mail: audiojoysmile@gmail.com

Husieva Marharyta, Graduate student of the chair ,Vocal-choral mastery” of Dnipropetrovsk Music Academy after Mikhail Glinka tel. (073) 159 - 89 - 17 e-mail: madambaterflai69@gmail.com

\title{
FEMALE IMAGES IN OPERA CREATIVITY OF THE AMERICAN COMPOSERS
}

The purpose of this article is to analyze and understand the interpretation of female images in the works of Opera composer's national American school. One of the reasons, which prompted the author to dive into the problem and answers Opera performances of American composers such as K. Floyd, John. K. Menotti, J. Gershwin. Methods. In achieving this goal, applied the following research methods a namely the source, comparison, systematization, analysis, generalization of the research problem, used many specialized works on the theory and history of culture. Scientific novelty of the work is that needs to expand views about the development of the Opera genre in American music. In addition, the inspection should be disclosed images of women in the perspective of self-identity of American music like the classic design in the field of Opera. This is due to the necessity of paying attention by the singer relative to the faithful and meaningful interpretation of the female character (Clara - George. Gershwin), Susanna K. Floyd, Monica K. Menotti), as in the dramaturgic sense, and the performing, as well as the emphasis on the vocal abilities of the singer and his acting skills. Conclusions. The analysis of this study was to identify patterns in the musical and thematic material of American Opera composers (K. Floyd, John. K. Menotti, J.Gershwin). In the plots of the operas presented by the harsh realities of the treatment of women 
at that time. In the women's images traced the line of resistance, the struggle for the future bright and strong-willed traits. The suffering and pain which resonates with the despair, but at the end of the story, spill over into the acceptance of his dark fate. Singer, in the performance of these works, will be able to learn the history of the characters, to understand their national and ideological features, for a more accurate interpretation of the characters in the performance of solo numbers in the Opera. Note also that the transformation of women's images, which provides an opportunity to trace the psychological and spiritual aspects of their development. This primarily happens due to the influence of social, political and historical moments.

The key words: female character, drama, American Opera, Opera music, Genesis, Opera, American school of composition.

Фурдуй Юлія Володимирівна, кандидат мистецтвознавства, доцент кафедри „Історія та теорія музики” Дніпропетровської академії музики ім. М. Глінки

Гуссва Маргарита Сергіївна, магістрант кафедри „Вокальнохорова майстерність" Дніпропетровської академії музики ім. М. Глінки

\section{Жіночи образи в оперній творчості американських композиторів}

Мета статті - проаналізувати й осмислити трактування жіночих образів в оперній творчості композиторів національної американської школи. Однією з причин, яка спонукала автора до занурення у дану проблему, - недослідженість оперної творчості американських композиторів, таких як К. Флойд, Дж.К. Менотті, Дж. Гершвін. Методи. У досягненні поставленої мети, застосовано наступні методи наукового дослідження, а саме - джерелознавчий, порівняння, систематизація, аналіз, узагальнення досліджуваної проблеми, використання праць 3 теорії та історії культури. Наукова новизна роботи полягає у потребі розширення уявлень щодо становлення оперного жанру в американській музиці. Також, здійснюється розкриття жіночих образів в ракурсі самоідентичності американської музики як класичного зразку в оперному жанрі. Це обумовлено необхідністю звернення професійної уваги виконавцявокаліста щодо потрібного та чітко осмисленого трактування жіночих персонажів (Клари - Дж. Гершвін, Сусанни - К. Флойд, Моніки - К. Менотті), як у драматургічному сенсі, так й у 
виконавському; а також здійснення акцентування на вокальних здібностях співака та його акторських навичках. Висновки. У ході аналізу оперних партій були виявлені закономірності в музичному та сюжетному матеріалі американських оперних композиторів К. Флойда, Дж.К. Менотті, Дж. Гершвіна. У сюжетах опер представлені суворі реалії ставлення до жінок того часу. У жіночих образах прослідковується лінія спротиву, боротьби за майбутнє; виявлені яскраві вольові риси. Їх страждання та біль перегукуються 3 відчаєм, але у кінці сюжету перетікають у прийняття власної важкої долі. Вокаліст, при виконанні означених творів, зможе ознайомитись із історією персонажів, зрозуміти їх національні та світоглядні особливості, задля більш точного трактування персонажів при безпосередньому виконанні сольних номерів опери. Також відзначимо, що відбувається трансформація жіночих образів, що надає можливість прослідкувати психологічний та духовний аспект їх розвитку. Насамперед, це відбувається за рахунок впливу соціальних, політичних та історичних моментів.

Ключові слова: жіночій образ, драматургія, американська опера, оперна творчість, генезис, опера, американська композиторська школа.

Фурдуй Юлия Владимировна, кандидат искусствоведения, доцент кафедры „История и теория музыки” Днепропетровской академии музыки им. М. Глинки

Гусева Маргарита Сергеевна, магистрант кафедры „Вокально-хоровое мастерство” Днепропетровской академии музыки им. М. Глинки

Женские образы в оперном творчестве американских композиторов

Цель статьи - проанализировать и осмыслить трактовку женских образов в оперном творчестве композиторов национальной американской школы. Одной из причин, которая побудила автора к погружению в данную проблему, неисследованность оперного творчества известных американских композиторов, таких мастеров как К. Флойд, Дж.К. Менотти, Дж. Гершвин. Методы. В достижении поставленной цели, использованы следующие методы исследования: источниковедческий, сравнение, систематизация, анализ, обобщение исследуемой проблемы, а также использованы труды по 
теории и истории культуры. Научная новизна работы заключается в том, что существует необходимость в расширении представлений о становлении оперного жанра в американской музыке. Также, к рассмотрению генерируется раскрытие женских образов в ракурсе самоидентичности американской музыки как классического образца в оперном жанре. Это обусловлено необходимостью обращения внимания исполнителя-вокалиста к наиболее точной и осмысленной трактовке женских персонажей, а именно Клары Дж. Гершвина, Сусанны - К. Флойда, Моники - К. Менотти, как в драматургии, так и в исполнительском аспекте; а также акцентировании на вокальных способностях певца и его актерских навыках. Выводы. В ходе анализа оперных произведений были выявлены закономерности в музыкальном и сюжетном материале американских оперных композиторов К. Флойда, Дж. К. Менотти, Дж. Гершвина. В сюжетах опер представленны суровые реалии отношения к женщинам того времени. В женских образах прослеживаются линии сопротивления, борьбы за будущее; яркие волевые черты. Их страдание и боль перекликаются с отчаянием, но в конце сюжета перетекают в принятие своей тяжелой судьбы. Вокалист, при исполнении данных произведений, сможет ознакомиться с историей персонажей, понять их национальные и мировоззренческие особенности для более точной трактовки образов при исполнении сольных номеров оперы. Отметим также, что происходит трансформация женских образов, которая предоставляет возможность проследить психологический и духовный аспект в их развитии. Прежде всего, это происходит за счет влияния социальных, политических и исторических моментов.

Ключевые слова: женский образ, драматургия, американская опера, оперное творчество, генезис, опера, американская композиторская школа.

Formulation of the problem. An opera that has been around for more than four centuries, it has come a long way from drama to musica to its contemporary look. It should be noted that in modern opera there are major stylistic changes, as well as updating of the genre in general. Emphasize, as E. Kiseeva points out: „The process of renewal was facilitated by the introduction of elements of mass culture into the opera genre. The influence of new media and media affected the peculiarities of the organization of opera texts, the principles of structuring the 
artistic whole. The influence of the masculinity determined the composers interest in the implementation of the subjects and topics related to the most important social, political and economic events" [4].

On this basis, it would be important to identify the specifics of female images in American national professional opera by such composers a namely J. Gershwin, K. Floyd, J.K. Menotti, for a better perception by the vocalist of the main female image, a character who in turn can give the listener the opportunity to receive the spiritual experience that is the main component of our lives.

The relevance of the research is of primary practical importance. The cultural modern space of man is created in the form of information flow. New genres that are of interest to the public are available for perception. Amidst such a diversity of performing and performing arts, opera, while remaining a fundamental genre in music, loses its audience. Therefore, it is necessary to enrich the modern repertoire of Ukrainian opera vocalist by joining a national American composer school, and to draw the listener's attention to the genre of opera in general. The need to study this issue is urgent in today's realities.

The literature review on the outlined issues can be divided into several directions, namely - the history of American music and its evolution is presented in the work of D. Collier [6]; the chronology of the evolution of culture is reflected in [3]; the question of ethnicity and melody, which later penetrated the opera genre of the national sample, is portrayed by V. Konen [5]; J. Gershwin's creativity and life path is outlined in the monograph of the same name by E. Volynsky [1]; problems of analysis of the opera „Porgy and Bess”-V. Zamyatin [2]. Also presented are a number of contemporary scientific music studies that expose the genesis and musical language of jazz music - W. Sargent [9]; L. Hanin [11] addresses the subject of T. Kuryshev's development of theatricality [8] and J.K. Menotti's opera house.

The purpose of this represented article is to investigate and reveal the dramatic features of the main female characters in the operas „Porgy and Bess” (J. Gershwin), „Susanna” (K. Floyd), „Medium” (J.K. Menotti).

The object of study is the opera creativity of American composers, their contribution to the opera arts and the leading repertoire of modern opera singers, and the subject of research are female images (Clara „Porgy and Bess” (J. Gershwin), Monica - „Medium” (J.K. Menotti), 
Susannah - „Susanna” (K. Floyd)) in American operas, their individuality and resemblance to the images of the classical model.

Presenting main material. At the beginning of its existence, the music of the people of America, absorbed the features of western and traditional music of America (J. Gershwin „135 Street”, „Porgy and Bess"; A. Copland „The Tender Land"). Later, in later samples, American composers used the acquisitions of musical minimalism (F. Glass, „Einstein on the Beach” (1979), „Satyagraha” (1985), „Akhenaten” (1987) and J. Adams „Nixon in China” (1995).

The history of American theater and American opera is very closely connected with the development of domestic and entertaining and so-called „mass" culture of this country. Opera is a synthesis of many kinds of arts. Let us dwell on the most recent opera genre in America.

The first American settlers - Puritans (Latin puritas ,purity”), English Protestants, who held the idea of their exclusiveness, they considered themselves ,the people chosen by God". But it should be noted that they brought with them strict church psalms and a strict ban on any kind of secular music. But the Quaker, Baptist, and German colonial religious communities in Pennsylvania freely cultivated music both in church and in everyday life. The Anglican Church also did not interfere with musicians. The musical life of the southern states, inhabited by the French and Italians, developed intensively. Boston, New York and Philadelphia were the largest music venues in the mideighteenth century [3].

America in the early XX century - was a young great country may at that time nowhere in the world have such a diversity of people, opinions, attitudes, and primarily, what we are most interested in, is a large reservoir a variety of national folklore. Folk music has inspired and built the Foundation for classical genres. Folk music of almost all regions of Europe - from the Slavic to the Scandinavian, black folklore, native, Indian, etc.

In the development of American Opera, a considerable role was played by such American composers: John Gershwin, George K. Mennot. And unfortunately, its classic example of American Opera in the early twentieth century had. Didn't exist the model of the national Opera in America.

In each country, the formation of a national music school is different. Common principle of the creation of national samples of 
various academic genres does not exist in history, especially such a monumental Opera. And yet, different in style and artistic value, all of the national Opera match one common condition: they embody the advanced national ideals, with the help of artistic images, in contradiction to the spirit, culture, ethnic of household, stratum of life of the people.

The founder of the American national professional Opera can be considered J. Gershwin. He dreamed of becoming a real composer to master all the genres to create works of large form.

The history of creative success George. The unique Gershwin, the composer, having no special education, was a brilliant piano virtuoso, one of the most popular composers of America, and then Europe. In the beginning of his career he had inspiration from genres of folk music (songs, jazz) that were developed at that time in America.

Recognizing the lack of knowledge of classical harmony, a composer began to study musical academic discipline. In Paris he took lessons from Maurice Ravel, who, in our opinion, influenced the composer's work and contributed to the development of the American school of composition. Namely, a fresh perspective on music, the desire for creative experimentation.

$\mathrm{V}$. Konno noted that ,to date, the origin and the aesthetic essence of this kind of art" (as was interpreted by critics of the time, the composer), remains a matter for debate [5, 65]. Features of black folklore, whimsical, intertwined with the music of the American lung genres (songs, dances). Bright originality, sharp expressiveness is combined with audacity and looseness inherent in the American stage.

J. Gershwin in the Opera „Porgy and Bess” outlined the problems of society - social, moral principles of the time. The Opera is based laid the humanistic idea, which shows the problems of African Americans due to the time in which the unfolding events of the Opera. The idea is that the composer, through his creativity and musical images, the characters showed humanity, concern for the fate of man in society, and tried to attract the attention of other people to such a phenomenon as a Person and treat her with respect.

The question arises why the life of an African-American social groups becomes the main theme of today's General American national Opera? This question may only be answered by digging into the culture, issues and history of that time. It outlined the Hayward in his play „Porgy and Bess", based on which was created the libretto of the Opera. 
The premiere took place on 30 November 1935 „Colonel-theater” in Boston.

In the Opera „Porgy and Bess" for the first time in the history of musical theater United States African Americans are shown with deep respect and compassion. Never before has an American music not sparkled with such a variety overheard from the people of intonations. The origins of expressive means: the Blues and spirtuals, spiritual hymns and elements of jazz, Negro labor songs and street songs of newsboys, the tradition of European lyrical-psychological Opera.

, «Porgy and Bess», keeping the operatic form, is a folk Opera. I had to find special methods for the image in music - drama, humor, religious thought and the irrepressible temperament of the people" wrote George Gershwin [1].

On the basis of the relevance of this work, the object of the analysis is presented with the image of Clara. Although the image and minor, but it is a critical prototype in the review of female characters in American Opera. Stop the attention on Clara's lullaby „Summer Time” from the first picture the first act of the Opera, which became a ,visiting card" of the Opera.

A lullaby written for a high soprano style sprouls, in couplet form. At the moment lullaby performed in the concert interpretations are not only high, but low female voice. As evidenced by its presence in the repertoire of Ella Fitzgerald (mezzo-soprano) - African-American singer with a world name.

In her interpretation of lullabies has gained a cult value and outside the Opera sounds on the concert stage as an independent work of a jazz nature.

Intonational background lullaby, flexible and wavy. This music is already a Mature singer with certain skills, including singing (lullaby cantilena and sprouls). The combination of classical canons (intervale, rhythm) and intonation descending intervals, the dotted rhythm of AfroAmerican music. John. Gershwin influenced his followers, who continued to build and strengthen American Opera in the future.

The most significant contribution to American national Opera by the composer J.K. Mennotti. Creativity J.K. Mennotti is one of the most remarkable phenomena in American Opera of the post-war decades. This the composer has opened new musical worlds, but his strength was in the ability to feel what requirements or that the story makes the music and, perhaps most importantly - how it will be perceived by people. 
The composer skilfully masters the art of Opera as a whole: he himself wrote the libretto of his operas, often places them as directed and supervises the execution as a brilliant conductor [8].

The appearance of the operas of Giuseppe Verdi K. Menotti looked forward to, the execution was widely reported in the press, aroused the interest of professionals and students. His most famous Opera is popular not only in USA but around the world: Opera „The Consul” has been translated into a dozen languages and staged in twenty-two countries; „Phone" is translated into five languages and delivered in fifteen countries; "Amal and the night visitors" has been translated into five languages, and in different years was broadcast during Christmas in the Netherlands, Italy, Germany, France, England, Sweden, Australia; "Medium" was translated into four languages, was repeatedly raised in Canada, Iceland, Argentina, Israel, Australia, France, Germany, Austria, Italy, England, Holland; the Opera ,with the Holy Bleecker street” saw the people of Canada, England, Italy.

Start your way as an Opera composer from the stories entertaining anecdotal plan, John. K. Menotti soon turned to dramatic subjects. However, his first attempt in this kind (the Opera ,the island God", 1942) was unsuccessful. But in 1946, appeared Opera-tragedy „Medium”. For several years she was screened and won an award at the Cannes film festival. So, Opera-tragedy „Medium”, which was recognized, was a significant contribution to American culture. It was established on an unusual story. The main characters of the Opera: Madame flora (mezzo-soprano), Monica (soprano), You (a mute role).

The Opera is the iconic Aria Monica's „The Black Swan”. This drama lullaby, which felt mystical elements, due to mystical story. This lullaby Monica wants to reassure his mother.

Aria was included in the anthology of American Opera: it is published in the manuals as a training repertoire for soprano next to other masterpieces of world classics.

An example of this Aria is given in the collection of G. Schirmer „Opera Anthology. Arias for Soprano" as a perfect example of the Opera composer, whose work is, unfortunately, in our country is not as popular as the birthplace of the author.

The second for popularity after „Porgy and Bess” the Opera is now considered the Opera „Susanna”, composer K. Floyd, the libretto written by the composer himself. Opera in two acts, on the theme of the 
American South, which portrays the daily life, psychological norms and experiences of the characters.

Like John. Gershwin, K. Floyd swept popular culture in music through the folk music of the Appalachian people (people who lived in the Appalachian mountains, in our case it is the southern Appalachians). The composer himself was born in the South, so the themes of the South, local customs, habits of the society he was familiar with.

$\mathrm{K}$. Floyd wrote their own national Opera as allegory ,the sociopolitical climate", in some States of America 50-ies of XX century.

The story of the opera was a biblical scripture story (Chapter 13 of Daniel's book), namely „Susannah and the Elders”, which featured many artists, such as P. Rubens, Rembrandt, P. Varonez, G. Moreau and others. The story of the opera is about an orphan girl who had a more relaxed demeanor, but not people throughout the town, which caused her problems with the religious community that made her an outcast.

One of the leading numbers of the opera is the aria „The Trees on the Mountain", which is based on folk songs of the Appalachian people. The lyric Aria, for a high voice, is written in a verse form that has the signs of lullaby. Ariana is executed by Susanna, she is filled with despair and not understanding to the reality that is happening in the town.

Folk music plays a central role in Susanna's opera, folk and jazz combined with Giacomo Puccini's poeticism and realism. By the way, J.Puccini himself wrote an opera on the subject of the southwest of America, an opera called „Girl from the South”.

Conclusions. In the course of the work dramaturgical features of female images in the operas „Porgy and the Bess” by J. Gershwin, „Susanna” by Carlyle Floyd, „Medium” by J. Carl Menotti were analyzed, and regularities in their structure were revealed. The operatic plots of these operas reveal the hard destinies and austere life of ordinary people. The music is based on folk music, an ethnos of the peoples of America combined with the classic rules of the opera genre. All operas trace the detail of time, characters, ethnicity and the social stratum of people using linguistic means (dialect, simple words spoken by the characters), folk tunes at the heart of musical fabric.

The dramaturgy of the operas is mostly based on the topics of social inequality in certain social groups (religious communes, racial prejudices, poverty). Mass scenes (choirs, ensembles), in operas depict the everyday life of ordinary people of that time (opera heroes). 
Female characters in the operas of American composers play a leading role, not only through musical expressive means. Powerful dramaturgy forms a new prototype of the weak woman in the modern world, reflects the social and moral problems of society, as well as the influence on opera heroes in different sections of the population and in different living conditions.

Prospects for this represented study - to draw attention to the formation of the canonical female image in American opera, to identify particular features and to draw the attention of Ukrainian performers to the creativity of the composers of the national American school and to include numbers from American operas, to the concert and educational academic repertoire.

\section{Список використаних джерел і літератури:}

1. Волинский Э. Дж. Гершвин: популярная монография. Ленинград: Музыка, 1988. 91 с.

2. Замятин В. Проблема анализа оперы Джорджа Гершвина „Порги и Бесс” в североамериканском музыкознании конца XX - начала XXI века: автореф. ... канд. искусствоведения: 17.00.02. Саратов, 2013. 26 с.

3. Келдыш Ю. Опера. Музыкальная энциклопедия. Москва: Советская энциклопедия, 1978. Т. 4. Стб. 20-45.

4. Кисаева Е. Проблема обновления оперного жанра в творчестве современных американских композиторов. Музыкальный театр рубежа XXХХІ веков: проблема обновления жанров. 2018. С. 42-46.

5. Конен В. Пути американской музыки. Очерки по истории американской культуры США. Москва: Музыка, 1965. 525 с.

6. Коллиер Д. Становление джаза. Москва: Радуга, 1984. 390 с.

7. Крылова А. Современный музыкальный театр в многообразии жанровых решений. Музыкальный театр рубежа XX-XXI веков: проблема обновления жанров. 2018. С. 84-89.

8. Курешева Т. Театральность и музыка. Москва: Советский композитор, 1984. $200 \mathrm{c}$.

9. Сарджент У. Джаз: генезис, музыкальный язык, эстетика. Москва: Музыка, 1987. $296 \mathrm{c}$.

10. Стрыгина Е. Музыка XX века. Байск: „Бия”, 2006. 282 с.

11. Ханина Л. Оперный театр Джан Карло Менотти : автореф. дис. ... канд. искусствоведения: 17.00.02. Москва, 2011. 31 с. 


\section{References:}

1. Volinskij, Je. (1988). J. Gershwin: popular monograph. Leningrad: Muzyka [in Russian].

2. Zamjatin, V. (2013). The problem of the analysis of George Gershwin's opera "Porgy and Bess" in North American Musicology at the end of the $20^{\text {th }}$ - the beginning of the $21^{\text {st }}$ century. Extended abstract of candidate's thesis. Saratov [in Russian].

3. Keldysh, Ju. (1978). Opera. Musical Encyclopedia. Moskva: Sovetskaja jenciklopedija [in Russian].

4. Kisaeva, E. (2018). The problem of updating the opera genre in the works of modern American composers. Muzykal'nyj teatr rubezha XX-XXI vekov: problema obnovlenija zhanrov, 42-46 [in Russian].

5. Konen, V. (1965). Ways of American music. Essays on the history of American culture of the USA. Moskva: Muzyka [in Russian].

6. Kollier, D. (1984). The becoming of jazz. Moskva: Raduga [in Russian].

7. Krylova, A. (2018). Modern musical theater in a variety of genre solutions. Muzykal'nyj teatr rubezha XX-XXI vekov: problema obnovlenija zhanrov, 84-89 [in Russian].

8. Kuresheva, T. (1984). Theatricality and music. Moskva: Sovetskij kompozitor [in Russian].

9. Sardzhent, U. (1987). Jazz: genesis, musical language, aesthetics. Moskva: Muzyka [in Russian].

10. Strygina, E. (2006). Music of the $20^{\text {th }}$ century. Bajsk: „Bija” [in Russian]. 11. Hanina, L. (2011). The opera house Gian Carlo Menotti. Extended abstract of candidate's thesis. Moskva [in Russian]. 